\title{
Tax Administration Reform: Impact of Taxpayers' Trust and Power of Tax Authority on Taxpayer Compliance
}

\author{
Davin Andika ${ }^{1}$ and Milla Sepliana Setyowati ${ }^{2}$ \\ \{davinandika15@gmail.com¹,milla.s.setyowati@gmail.com² \\ Faculty of Administrative Sciences, Universitas Indonesia, Depok, West Java, Indonesia ${ }^{1}$ \\ Faculty of Administrative Sciences, Universitas Indonesia, Depok, West Java, Indonesia ${ }^{2}$
}

\begin{abstract}
Referring to slippery framework, taxpayer compliance can be measured using taxpayer trust and power of tax authority in order to obtain comprehensive output. This research is addressed to analyze taxpayer's trust and power of tax authority of Large Tax Office Two as well as analyzing the impact of taxpayer's trust and power of tax authority towards taxpayer compliance. The research employs mixed methods approach. In quantitative side, this research collected data from questionnaire and is processed using descriptive statistics, regression, and coefficient determination tests. In qualitative side, this research collected the data from interview and was processed for triangulation objective and enriching output obtained from quantitative approach. This research revealed that taxpayer's trust and power of tax authority lie on different level and performed significant impact on taxpayer compliance by $57.2 \%$ in Large Tax Office Two. It is suggested that Large Tax Office Two needed to control its authority and power to prevent it from being either weak or arrogant.
\end{abstract}

Keywords: Tax Compliance, Taxpayer Trust, Power of Authority.

\section{Introduction}

State budget and revenue has been increasing annually, therefore target of tax revenue has been increasing as well. Nevertheless, it contradicts with tax ratio of Indonesia is considered to be the lowest in the world by $11 \%$. In line with the need to increase tax revenue and low tax ratio, the government to formulate accurate strategy to overcome the problem. One of the strategies to increase tax ratio and government revenue is to improve taxpayer trust.

Referring to Kirchler, Hoelzl, and Wahl [1] there are two dimensions of taxpayer trust based on slippery slope framework which are taxpayer trust and power of tax authority. Trust, or is frequently called as trust, is considered to extraneous variable in administrative research, while trust is urgent in the process of administration enforcement. Recently, the government of Indonesia, through Directorate General of Tax, has been attempting to improve voluntary compliance of taxpayer. Referring to Kirchler et al., the authors are interested to observe the taxpayer compliance.

Object of this research is Large Tax Office Two as it is one the tax office that has performed significant contribution towards tax revenue. According to ex General Director of 
Tax Ken Dwijugiasteadi, the contribution of Large Tax Office Two has reached $32 \%$ of the total national revenue. Directorate General of Tax has four Tax Office (KPP) Large Taxpayers, still, it is more appropriate to take Tax Office (KPP) Large Taxpayer One and Two as the research object. Taxpayers registered in Tax Office (KPP) Large Taxpayer Three and Four are stateowned enterprises, thus it would be considered less-objective (if Tax Office (KPP) Large Taxpayer Three and Four are included as the research object) [2].

Large Tax Office Two has the highest revenue realization compared to other tax offices in Indonesia. According to Performance Report 2016 [3], Large Tax Office Two set the target of tax revenue by Rp. 140 trillion, while the revenue realization reached Rp. 104 trillion. It means the realization of Large Tax Office Two has successfully reached $74 \%$ of the $100 \%$ revenue target. Therefore, Large Tax Office Two becomes the most appropriate research object (due to its highest contribution on tax revenue realization) to analyze the impact of taxpayer's trust and power of tax authority on taxpayer compliance.

Objective of this research is to analyze taxpayer trust on Large Tax Office Two and to analyze power of the authority of Large Tax Office Two, to analyze the impact of taxpayer's trust on taxpayer compliance, and to analyze the impact of power of tax authority on taxpayer compliance.

\section{Literature Review}

\subsection{Taxpayer Trust}

Kim [4] conducted analysis on variables that have been employed by the previous researches that measured public trust. In regards with that matter, Kim argued that there are five dimensions that can be used to measure public trust. They are credibility of commitment, benevolence, honesty, competencies, and fairness. Detail description is explained by Dwiyanto [5] as follow:

1. Credible Commitment

Hardin in Kim expressed that credible commitment as "encapsulated interest of government actor to honor her agreement or to act according to certain standard." Credible commitment, according to Hardin in Kim, can be measured using two indicators which are encapsulated interest and consistency.

Encapsulated interest can be defined as common interest between government and the public. Besides that, the public also believed that any government acts are always be based on the aim to achieve common goods or to protect public interests. This indicator would come up only when the government always acts on behalf on public interests in formulating policies.

Consistency means consistent act of the government (and its officials) in taking actions. If public considers the government has consistency to solve problems and perform strong public concern, public would consider the government (and its officials) perform high commitment and credibility to public interests.

2. Benevolence

A government official will not do abuse of power, even they are not supervised, if they have sincerity. This dimension is one of important factors that is responsible upon public trust crisis to government. Government officials would not take benefit from public services for their personal interest. The government officials are considered sincere if they do not abuse public interest, even those officials are frequently watched by the public 


\section{Honesty}

Honesty is actually an important dimension to explain trust. If public considers the government officials are not honest, then public trust would disappear or diminish. Honesty perception is established from public judgement on public official behavior when delivering public services or established from publication of mass media. Any information about government official behavior would impact level of public trust towards government honesty. In the other hand, public interaction would also affect perception towards government honesty.

4. Competency

Competency of government, officials, and staff would affect public trust. The ability of the government in running their function, such as delivering public services, would increase public trust towards government performance. Public would have high trust if they consider the government and the officials are able to comprehensively understand and solve problems. Besides that, the government officials are also considered performing high capacity if they have high capability on their fields.

5. Fairness

Fairness is one of important dimensions to represent trust. Fairness, according to public perspective, is considered from the way the government officials deliver their services to the public. The consideration or judgement refers to the principle of justice perceived by the public.

If the principle and fairness values embraced by the government are in the same frequency with public perspective, then it would increase public trust towards government performance. However, if public perceives discrimination in the context of social interaction, ethnicity, belief, political affiliation, etc, it would ruin fairness perception of the public. Therefore, the government and officials are expected to embrace the principle of fairness and transparency in performing public services. That way, public would consider government perform high integrity.

\subsection{Power of Tax Authority}

According to Turner (2005) and Tyler (2006) in Hofmann, Gangl, Kirchler, and Stark [6] in psychology science, the quality of power of tax authority can be divided into coercive power and legitimate power. The followings are five instruments to measure authority (power of tax authority) expressed by French and Raven (1959) in Raven, Schwarzwald, and Koslowsky [7]:

1. Coercive power is a power that comes up due to threats upon existing law.

2. Reward power is promises upon compensation delivered to public for their obedience.

3. Legitimate power is power of authority coming from particular rights of a person or a party to interfere others in a structural relationship

4. Expert power is an authority that relies on expertise or knowledge of a person or a party expected to drive public perspective to always count on the government as the institution who knows what best to do. According to Raven, the legitimate power has more benefit compared to coercive power and reward power. It would also prevent any problems that may incur from legitimate power if it runs effectively.

5. Referent power is a power that comes up from a perspective that public and government officials have the same interest

6. Moreover, according to Raven there are six fundamental bases of power of authority by adding informational power based on logical information and argumentation that government officials have strong influence and would bring positive changes for the public. 
According to Raven [8], there are six fundamental bases of power as follow:

1. Informational Power

Superordinate clearly delivers direction to subordinates that a particular job or tasks that must be executed in different way and provides persuading explanation so that it would be considered as better and effective procedures. That way, subordinates would understand, accept, and change their behavior. This power affects and changes acceptance and cognition of a target. This power is often called as socially independent change.

2. Reward Power and Coercive Power

Reward power is an ability of a leader to offer positive incentives if the target is fully achieved, while in coercive power, leader tends to deliver negative threat to subordinates if they are not obedient. These two types of power are often called as socially dependent power as target will only be achieved if leaders deliver either positive incentives or negative threats (if subordinates are not obedient). However, if the target considered the authority cannot detect disobedience, the target tends to be disobedient.

Coercive power is different from reward power in terms of surveillance. The benefit of reward power is target would express their obedience, while in coercive power target tends to hide their disobedience. Therefore, the authority has to proactively identify it.

Besides that, coercive power stimulates feel of being threatened, being forced, and being hateful to the authority due to coercion from the authority to subordinates to act in a particular way.

3. Legitimate Power

This power comes from target acceptance upon authority power to make changes and target is obliged to obey superordinate. The terms to represent legitimate power are "oblige", "obliged", "require", "required", and "should".

4. Expert Power

Expert power basically comes from target's belief that leader or superordinate must have higher knowledge or perspective regarding the best attitude/behavior in a particular situation. The difference between expert power and informational power are excuse understanding, where understanding on excuses is not required in expert power.

5. Referent Power

Referent power comes from target recognition towards leaders/superordinate or considering leader as a good example.

\subsection{Taxpayer Compliance}

According to Kogler, Muehlbacher, and Kirchler [9] distributive fairness refers to resource exchange/transfer in terms of cost and benefit that may incur from a tax system. Retributive fairness refers to suitability of a sanction due to particular disobedience. Based on that sense, non-sense audit, and unfair sanction will drive negative perception from taxpayer to tax system and tax authority. It means that negative perception on retributive fairness will reduce taxpayer's trust towards tax authority. As the consequences, it will affect voluntary compliance. According to Kirchler et al., in Kogler et al., as perception on retributive fairness is highly dependent on the ability of the authority to detect and to sanction tax evaders.

According to Braithwaite [10], the relationship between taxpayers and tax authority can be modelled as a relationship contract that contains strong emotional bond and loyalty to smoothen any transaction. It means that the chemistry between taxpayers and the government (which is tax authority or Directorate General of Tax) need to build synergy to create stronger trust and compliance or trust to each other. According to Shcein; Rousseau and Mclean Parks in Braithwaite expressed that social psychology science employed the concept of "psychological 
contract" to separate it from formal contract but still complied as the two parties agreed upon material and explicit sanction.

There five important motivational postures in explaining tax compliance. They are commitment, capitulation, resistance, disengagement, and game playing. Commitment actually reflects belief on what is actually desired by tax system and reflect morale responsibility to act on behalf of common interest through voluntary tax compliance. In the other hand resistance behavior actually reflects doubt towards intention of tax authority so that taxpayers would be more careful and fight for their rights by limiting the movement of tax authority. According to Wahl, Kastlunger, and Kirchler [11] voluntary compliance is operationalized with commitment from motivational postures, and forced compliance is operationalized by resistance.

\section{Methods}

This research employs mixed method approaches. According to Hanson as stated by Hesse and Sarwono [12], mixed method is collection, analysis, and integration of qualitative and quantitative data in a single or sequential study. This research is addressed to measure the impact of taxpayer's trust and power of tax authority towards taxpayer compliance. The research employs concurrent triangulation. The author realizes that any methodology must have strengths and weaknesses. According to Creswell [13], this method employed quantitative and qualitative data collection simultaneously. With this combination, it is expected to generate comprehensive output.

Data of this research is collected from questionnaire for the qualitative ones, and in-depth interview and literature study for qualitative ones. Questionnaire and in-depth interview are addressed to respondents registered in Large Tax Office Two as well as conducting interview with reputable academicians. Population of this research is 250 taxpayers registered in Large Tax Office Two, thus the sample size is 72 respondents. In determining research sample, the research employs accidental sampling.

Data analysis technique of this research consists of both quantitative and qualitative techniques. The quantitative analysis consists of tests on research instruments, classical assumptions, descriptive analysis, multiple linear regression, and coefficient determination test. In the qualitative analysis, the research describes qualitative data into narrative on this research. This narrative approach is applied in output deliverables. As this research employs qualitative as a complementary method, then qualitative data would be analyzed in the form of narrative to deliver comprehensive analysis.

\section{Analysis}

\subsection{Descriptive Analysis}

This research employs variable descriptive analysis to analyze data from each variable. Those variables are taxpayer's trust, power of tax authority, and taxpayer compliance. Descriptive analysis of this research is exhibited in the form following table.

Table 1: Variable Descriptive 


\begin{tabular}{cccccc}
\hline \hline & N & Minimum & $\begin{array}{c}\text { Maximu } \\
\mathbf{m}\end{array}$ & Mean & Std. Deviation \\
\hline Taxpayer's Trust & 73 & 1,54 & 3,88 & 3,0901 &, 34336 \\
Power of Tax Authority & 73 & 2,28 & 3,61 & 3,0084 &, 30227 \\
Taxpayer Compliance & 73 & 1,56 & 3,74 & 3,0025 &, 32154 \\
Valid N (listwise) & 73 & \multicolumn{5}{c}{ Source· data processing } \\
\hline \hline
\end{tabular}

Source: data processing

According to descriptive statistics result, taxpayer's trust obtained mean value by 3.09 within range between 1 to 4 . It means most of respondents chose to answer score 3, meaning they agreed. With standard deviation by 0.343 and is lower than the average, it expresses that respondent argument on taxpayer's trust is relatively homogenous. In general, the above table exhibits that taxpayer expresses trust towards Large Tax Office Two.

According to descriptive statistics output, variable of power of tax authority obtained score of mean by 3.01 within range of 1 to 4 . It means most of respondents chose to answer score 3 , meaning they agreed. With standard deviation by 0.302 and is lower than the average, it expresses that respondent argument on power of tax authority is relatively homogenous. In general, the above table expresses that taxpayers perceived Directorate General of Tax and Large Tax Office Two have legitimate power that tends to be coercive. According to descriptive statistics output, variable of taxpayer compliance obtained score of mean by 3.0 within range of 1 to 4 . It means most of respondents chose to answer score 3, meaning they agreed. With standard deviation by 0.322 and is lower than the average, it expresses that respondent argument on taxpayer compliance is relatively homogenous. In general, according the average score obtained from data processing, taxpayers of Large Tax Office Two decided to comply their tax obligation. According to interview with taxpayer respondents, by giving trust to Directorate General of Tax, they will be honest and will comply their tax obligation. Besides that, there are number of taxpayers who perceive that power of authority of Directorate General of Tax is a proof of assertiveness to make taxpayer comply.

This research also used multiple linear regression to analyze whether or not taxpayer trust and power of tax authority perform significant impact on taxpayer compliance. This research uses SPSS 20, and the result is exhibited by the following table.

Table 2: Output of Multiple Linear Regression

\begin{tabular}{|c|c|c|c|c|c|c|}
\hline \multirow{2}{*}{\multicolumn{2}{|c|}{ Model }} & \multicolumn{2}{|c|}{$\begin{array}{l}\text { Unstandardized } \\
\text { Coefficients }\end{array}$} & \multirow{2}{*}{$\begin{array}{c}\text { Standardized } \\
\text { Coefficients } \\
\text { Beta } \\
\end{array}$} & \multirow[t]{2}{*}{$\mathbf{t}$} & \multirow[t]{2}{*}{ Sig. } \\
\hline & & B & Std. Error & & & \\
\hline \multirow{3}{*}{1} & (Constant) & ,481 & ,286 & & 1,678 & ,098 \\
\hline & Taxpayer's Trust & ,535 & ,086 & ,572 & 6,249 & 000 \\
\hline & Power of Tax Authority & ,288 & ,097 & ,271 & 2,964 & ,004 \\
\hline \multicolumn{7}{|c|}{ a. Dependent Variable: Taxpayer Compliance } \\
\hline
\end{tabular}


Source: data processing (SPSS 20)

According to the above regression table, it can be seen that there is significant relationship between taxpayer trust on taxpayer compliance. It is proven by the significance value that is lower than alpha by 0.05 . With this result, $\mathrm{H}_{0}$ is rejected while $\mathrm{H}_{1}$ is accepted. Meanwhile, beta value is 0.572 and contains positive sign. It means there is moderate relationship between taxpayer trust and taxpayer compliance, where the higher the trust of taxpayer, the higher the compliance to meet their tax obligation. This finding is consistent with some previous researches by Muehlbacher, Kirchler, and Schwarzenberger [14] and Mas'ud, Manaf, and Saad [15] that taxpayer's trust significantly affected taxpayer compliance.

Moreover, it is also shown significant relationship between power of tax authority and tax compliance. It is shown by significance value by 0.004 , which is lower than alpha by 0.05 . It means $\mathrm{H}_{0}$ is rejected while $\mathrm{H}_{1}$ is accepted. Furthermore, beta value of this variable is 0.271 and it contains positive sign. It means that there is weak relationship between power of tax authority and taxpayer compliance. The result implies the higher the power of tax authority, the higher the taxpayer compliance. This research is consistent with some previous researches by Muehlbacher et al., and Mas'ud et al., that power of tax authority significantly affected taxpayer compliance.

According to the above result, taxpayer trust and power of tax authority of Large Tax Office Two would increase taxpayer compliance. This compliance is reflected by tax revenue realization in Large Tax Office Two. The following is table consisting tax revenue realization in Large Tax Office Two.

Table 3: Tax Revenue Realization in Large Tax Office Two (in Trillion Rupiah)

\begin{tabular}{ccccc}
\hline \hline \multirow{2}{*}{ Year } & \multirow{2}{*}{ Target } & \multicolumn{2}{c}{ Previous Revenue } & \multirow{2}{*}{ Realization } \\
& & Gross & Net & \\
\hline 2015 & 148,424 & 127,414 & 106,062 & $69,62 \%$ \\
2016 & 140,507 & 125,006 & 103,327 & $74,26 \%$ \\
2017 & 120,306 & 124,422 & 104,342 & $100,3 \%$ \\
\hline \hline
\end{tabular}

Source: Large Tax Office Two (2018)

According to the above result, it can be seen that tax revenue realization in Large Tax Office Two has been increasing along 2015 to 2017. It shows that compliance level in Large Tax Office Two has achieved good performance and keeps increasing. It means the achievement has actually been empirically influenced by taxpayer trust and power of authority of tax offices. In this research, the analysis of coefficient determination is run using SPSS 20. The following is the empirical finding of coefficient determination.

Table 4: Coefficient Determination of Taxpayer Trust and Power of Tax Authority on Taxpayer Compliance

\begin{tabular}{ccccc}
\hline \hline Model & R & R Square & Adjusted R Square & Std. Error of the Estimate \\
\hline 1 &, $741^{\mathrm{a}}$ &, 549 &, 536 &, 21892 \\
\hline \hline
\end{tabular}

a. Predictors: (Constant), Power of Tax Authority, Taxpayer Trust

b. Dependent Variable: Taxpayer Compliance Source: data processing (SPSS 20) 
According to the above result of coefficient determination test, the value of R-square is 0.549 . It means the coefficient determination of this research is $54.9 \%$. It indicates that $54.9 \%$ of changes in taxpayer compliance in Large Tax Office Two is empirically driven by taxpayer trust and power of tax authority. This result is consistent with previous research from Mas'ud et al., where the coefficient determination is $31.9 \%$.

Taxpayer trust affects taxpayer voluntary compliance. Nevertheless, the first step to take for Directorate General of Tax to obtain taxpayer trust is address trust to the public first, no actions without positive proof, being transparent by initially confirming it to taxpayer. In case public trust disappear, they would not be willing to pay taxes. According to interview result with taxpayers, they would be automatically honest and obedient if they have trust to tax authority. It means that trust influences taxpayer compliance.

The most sensitive issue among trust factors is honesty. It turns to be very sensitive because tax is actually related to money. The assumption is that when someone pays something when he/she has trust. When taxpayer has perception that Directorate General of Tax and government officials are honest, then tax policy delivered properly would be well-accepted by the public.

When it comes to honesty, low competence is not something to worry about, and taxpayer would understand it. Directorate General of Tax seems to be difficult to improve public trust as many tax-related problems came up such corruptions. The impact is that tax realization tends to decrease as public consider money, they pay for tax would be corrupted by tax officials, even admitted that such perception is actually wrong.

According to the interview with taxpayers, it is also revealed that they voluntarily comply the obligation as they realized that tax is the largest sources of government revenue that would be used to develop country and to help others. In the other hand, there are some taxpayers that do not really understand the important role of tax on the national development. It means that understanding and knowledge are not comprehensively perceived by taxpayers.

Power of tax authority would increase taxpayer compliance through many aspects. The first aspect is power of tax authority and actually a law enforcement where tax evaders would be sanctioned to get deterrent effect. It is also expected that tax officials would be fair to those who comply their tax obligations well. The second aspect is legitimation where tax authority is considered as respected and legal institution to collect tax from public.

The power of authority tends to be complex, as lower power would also lower compliance level of taxpayer. It is mainly due to no taxpayers meet their obligations to pay tax, and those who comply the obligation perceived unfair treatment from the authority as tax evaders are not properly sanctioned as they should be.

In the other hand if the power of authority is way too powerful, then compliance would also decrease. It is mainly due to perception that all taxpayers have the same position in the eye of tax authority, even tax evaders. This would decrease compliance level if the power of tax authority is was too powerful.

There are number of researches expressing that increase in compliance through power of tax authority is law enforcement. The weakness of this stance is high cost compared to voluntary compliance. Powerful authority tends to be coercive, thus the cost tends to be very high. In the other hand power of tax authority is required to improve tax revenue collection in the case of low trust of taxpayer. It is relevant to be implemented in Indonesia as public trust remain low. Besides that, trust is the most difficult aspect to obtain. It takes long period to obtain it, where it can be easily disappeared when many related cases come up to the public.

According to the interview with taxpayers, they tend to comply their tax obligation as they perceived that power of authority of Large Tax Office Two has included legitimation to collect tax, possible audit from tax offices, and existing regulation that guarantee any inappropriate 
actions would be sanctioned. Nevertheless, there are number of taxpayers who perceived that sanction imposed to tax evaders is still not optimal as it should be.

\section{Conclusion}

This research is addressed to identify the extent to which taxpayer trust and power of tax authority of Large Tax Office Two can significantly affect taxpayer compliance. According to the result, it can be concluded as follow.

1. According to the above result, it is obtained conclusion that taxpayer trust and power of tax authority of Large Tax Office Two are classified "fair." In general, taxpayers believed that Large Tax Office Two has run their mandated obligations based on sincerity, consistency, competence, honesty, and fairness aspects in delivering services. Taxpayer also believed that Large Tax Office Two had legitimation as tax office and has good law enforcement through proper sanctions for any inappropriate actions. It is reflected from the increase in both voluntary and forced tax compliance.

2. According to the above result, taxpayer trust significantly affected tax compliance by 0.572 . Taxpayer compliance performs strong contribution to taxpayer compliance, where the higher the taxpayer trust, the higher the taxpayer compliance of Large Tax Office Two. Taxpayer complied their tax obligations voluntarily as they realized that tax is the largest sources of government revenue that would be used to develop the country and to help others. Nevertheless, there are number of taxpayers who do not really understand the role of tax revenue on national development.

3. According to the above result of multiple linear regression, it is seen that power of authority performed significant impact on taxpayer compliance. The power of tax authority performed weak contribution towards taxpayer compliance, where the higher the power of tax authority, the higher the compliance level of taxpayers in Large Tax Office Two. In regards with power of tax authority, taxpayer tends to meet their tax obligations as they perceived that Directorate General of Tax and Large Tax Office Two have legitimation as legal institution to enforce tax collections, possible audit by tax offices, as well as existing law enforcement to anticipate any inappropriate fraud. Nevertheless, there are number of taxpayers who consider that sanction on tax evaders is not optimal as it should be.

\section{References}

[1] E. Kirchler, E. Hoelzl, and I. Wahl, "Enforced versus voluntary tax compliance: The 'slippery slope' framework," J. Econ. Psychol., vol. 29, no. 2, pp. 210-225, 2008.

[2] LAKIN: Laporan Kinerja, "KPP Wajib Pajak Besar Dua,” LAKIN: Laporan Kinerja, 2016. .

[3] Kementerian Keuangan, "DJP Beri Penghargaan 24 Wajib Pajak Besar," https://www.kemenkeu.go.id, 2016. .

[4] S.-E. Kim, "The role of trust in the modern administrative state: An integrative model," Adm. Soc., vol. 37, no. 5, pp. 611-635, 2005.

[5] A. Dwiyanto, Mengembalikan kepercayaan publik melalui reformasi birokrasi. Gramedia Pustaka Utama, 2013.

[6] E. B. Hofmann, K. Gangl, E. Kirchler, and J. Stark, "Enhancing tax compliance through coercive and legitimate power of authorities," WU Int. Tax. Res. Pap. Ser., no. 2013-01, 2013.

[7] B. H. Raven, J. Schwarzwald, and M. Koslowsky, "Conceptualizing and measuring a power/interaction model of interpersonal influence 1," J. Appl. Soc. Psychol., vol. 28, no. 4, pp. 307-332, 1998. 
[8] B. H. Raven, "The bases of power and the power/interaction model of interpersonal influence," Anal. Soc. issues public policy, vol. 8, no. 1, pp. 1-22, 2008.

[9] C. Kogler, S. Muehlbacher, and E. Kirchler, "Testing the 'slippery slope framework' among self-employed taxpayers," Econ. Gov., vol. 16, no. 2, pp. 125-142, 2015.

[10] V. Braithwaite, "Dancing with tax authorities: Motivational postures and non-compliant actions," Tax. Democr., pp. 15-39, 2003.

[11] I. Wahl, B. Kastlunger, and E. Kirchler, "Trust in authorities and power to enforce tax compliance: An empirical analysis of the "Slippery Slope Framework," Law Policy, vol. 32, no. 4, pp. 383-406, 2010.

[12] J. Sarwono, "Strategi Melakukan Riset," Cet. I, 2013.

[13] J. W. Creswell and J. D. Creswell, Research design: Qualitative, quantitative, and mixed methods approaches. Sage publications, 2017.

[14] S. Muehlbacher, E. Kirchler, and H. Schwarzenberger, "Voluntary versus enforced tax compliance: Empirical evidence for the 'slippery slope' framework," Eur. J. Law Econ., vol. 32, no. 1, pp. 89-97, 2011

[15] A. Mas'ud, N. A. A. Manaf, and N. Saad, "Do trust and power moderate each other in relation to tax compliance?," Procedia-Social Behav. Sci., vol. 164, pp. 49-54, 2014. 